\title{
KARAKTERISTIK BENIH KAYU BAWANG (Azadirachta excelsa (Jack) Jacobs) BERDASARKAN TINGKAT PENGERINGAN DAN RUANG PENYIMPANAN
}

\author{
Seed Characteristics of Kayu Bawang (Azadirachta excelsa (Jack) Jacobs) \\ Based on The Level of Seed Drying and Storage \\ Naning Yuniarti ${ }^{1)}$, Nurhasybi $i^{1)}$ dan/and Darwo ${ }^{2)}$ \\ ${ }^{1}$ Balai Penelitian Teknologi Perbenihan Tanaman Hutan \\ J1. Raya Ciheuleut Po. Box 105, Bogor 16001, Jawa Barat, Indonesia \\ Telp. (0251) 8327768; 8380065, Fax. (0251) 8327768 \\ ${ }^{2}$ Pusat Penelitian dan Pengembangan Hutan \\ Jl. Gunung Batu No. 5 Po. Box 165, Bogor 16610, Jawa Barat, Indonesia \\ Telp (0251) 8633234, Fax (0251) 8638111 \\ Email : naningbtp@yahoo.co.id; d_hasybi@yahoo.com; darwop3h@gmail.com
}

Tanggal diterima : 23 Februari 2015; Tanggal direvisi : 10 Oktober 2016; Tanggal disetujui : 5 Desember 2016

\begin{abstract}
Seed characteristics are important to be known for determining the proper seed handling techniques. The aim of this research is to reveal the characteristics of kayu bawang seed. The tests were conducted based on drying times $(0,24$, 48, 72, 96, 120 hours) and seed room storage (ambient room, air conditioned room, refrigerator). The results showed that kayu bawang seeds are belong to the recalcitrant seeds with initial moisture content of 57.21\%, germination percentage of $83 \%$, fat content of $17.04 \%$, carbohydrate content of $9.07 \%$ and protein content of $12.69 \%$. Drying rate and the room storage factors affected significanlyt on germination, moisture content, carbohydrate and fat content of kayu bawang seed, while the protein content was the only factor that had significant effect to period time of storage. Longer drying times decreased water content, germinationrate and carbohydrates content. In contrary, longer drying times increased fat and protein contents. Kayu bawang seeds can be stored at ambient room or air conditioned room and should be germinated shortly and it has to be planted.
\end{abstract}

Keywords: Azadirachta excelsa, characteristics, drying, seed, storage

\begin{abstract}
ABSTRAK
Karakteristik benih penting diketahui karena untuk menentukan teknik penanganan benih secara tepat. Penelitian ini bertujuan untuk mengeetahui karakteristik benih kayu bawang. Pengujian dilakukan berdasarkan tingkat pengeringan $(0,24,48,72,96,120$ jam) dan ruang penyimpanan benih (ruang suhu kamar, AC, kulkas). Hasil penelitian menunjukkan bahwa benih kayu bawang termasuk benih reklasitran dengan kadar air awal 57,21\%, daya berkecambah 83\%, kadar lemak 17,04\%, kadar karbohidrat 9,07\% dan kadar protein 12,69\%. Faktor tingkat pengeringan dan tempat penyimpanan benih berpengaruh signifikan terhadap daya berkecambah, kadar air, kadar karbohidrat dan kadar lemak benih kayu bawang sedangkan terhadap kadar protein hanya faktor waktu simpan yang berpengaruh nyata. Semakin lama benih dikeringkan mengakibatkan terjadinya penurunan kadar air, daya berkecambah dan kadar karbohidrat, namun meningkatkan kadar lemak dan protein. Benih kayu bawang bisa disimpan di ruang kamar atau di ruang AC dalam waktu singkat dan harus segera disemaikan.
\end{abstract}

Kata kunci : Azadirachta excelsa, karakteristik benih, pengeringan, penyimpanan

\section{PENDAHULUAN}

Salah satu jenis tanaman hutan yang potensial untuk dikembangkan sebagai hutan tanaman adalah kayu bawang. Kegunaan kayunya untuk konstruksi ringan, mebel, panel dan vinir. Untuk menunjang keberhasilan penanamannya, diperlukan penyediaan benih dalam jumlah yang cukup dengan mutu benih yang baik. Peningkatan jumlah dan mutu benih perlu diperhatikan untuk menjamin pengadaan bahan tanaman dalam program penanaman. Peningkatan tersebut diantaranya adalah melalui waktu yang tepat dalam pengumpulan benih, penanganan benih yang baik dan benar serta penyimpanan yang aman. Apabila langkahlangkah ini diikuti, maka program penanaman akan lebih berhasil (Yuniarti et al., 2013).

Teknik penanganan benih adalah semua kegiatan penanganan benih mulai dari benih 
dihasilkan sampai benih diuji dan disimpan agar mutu benih terjamin baik. Teknik penanganan dari masing-masing benih berbeda antara benih yang satu dengan lainnya, tergantung dari karakteristik atau watak benih. Berdasarkan potensi fisiologisnya, karakteristik benih dikelompokkan menjadi 3, yaitu benih ortodok, intermediate (semi ortodok atau semi rekal-sitran).

Benih ortodok merupakan benih yang toleran terhadap penurunan kadar air (kurang dari 10\%) dan penyimpanan pada suhu rendah; relatif lebih tahan disimpan dalam jangka waktu lama. Benih rekalsitran merupakan benih cepat rusak yang tidak tahan terhadap pengeringan dan tidak dapat disimpan pada temperatur rendah, sehingga tidak mampu disimpan lama. Benih intermediate (semi ortodok atau semi rekalsitran) merupakan benih yang mempunyai sifat seperti benih ortodok (dapat dikeringkan hingga kadar air agak rendah) tetapi tidak tahan terhadap temperatur rendah, seperti sifat pada benih rekalsitran (Yuniarti et al., 2011).

Cara penyimpanan benih ortodok, yaitu sebelum disimpan, benih dikeringkan sampai kadar air mencapai 5-8\%, kemudian benih dimasukkan ke dalam wadah kedap udara untuk menghindari penyerapan kembali kelembaban udara luar karena benih ortodok memerlukan wadah simpan yang kedap udara. Ruang simpan yang diperlukan untuk benih ortodok, yaitu suhu yang rendah, yaitu ruang simpan kering sejuk (suhu $18-20^{\circ} \mathrm{C}$, kelembaban nisbi 50-60\%), ruang simpan kering dingin (suhu $4-8^{\circ} \mathrm{C}$, kelembaban nisbi 40-50\%) dan ruang simpan dingin (suhu $10^{\circ} \mathrm{C}$ sampai $-15^{\circ} \mathrm{C}$, kelembaban nisbi $40-50 \%$ ). Benih ortodok dapat disimpan lebih dari satu tahun jika memperhatikan kondisi penyimpanan (kadar air benih, suhu penyimpanan) dan wadah simpan (Yuniarti et al., 2011).

Permasalahan yang sering timbul dalam pengadaan benih tanaman hutan adalah viabilitas dan vigor benih yang rendah, terutama jika disimpan dalam waktu yang cukup lama. Dibandingkan dengan benih ortodok dan intermediate, benih rekalsitran lebih cepat menurun viabilitas dan vigor benihnya selama proses penyimpanan karena benih rekalsitran cepat rusak dan tidak tahan disimpan. Benih rekalsitran akan mengalami penurunan mutu viabilitas benih, sehingga dapat menyebabkan perubahan menyeluruh di dalam benih baik fisik, fisiologis maupun kimiawi yang mengakibatkan menurunnya viabilitas dan vigor benih. Indikasi biokimia (lemak, protein, karbohidrat) dalam benih yang mengalami penurunan mutu benih adalah terjadinya perubahan aktivitas enzim, perubahan laju respirasi, perubahan dalam cadangan makanan, perubahan di dalam membran, kerusakan khromosom dan akumulasi bahan toksin (Tatipata, 2008). Selama proses pengeringan dan penyimpanan, akan menyebabkan menurunnya kadar air dan daya berkecambah, kandungan lemak pada benih cenderung meningkat serta menurunnya kadar karbohidrat dan kadar protein di dalam benih, sehingga mengakibatkan benih kehilangan energi untuk perkecambahan (Yuniarti et al., 2008).

Benih kayu bawang belum diketahui karakteristik benihnya. Untuk menentukan karakteristik fisiologis benihnya, diperlukan pengujian untuk mengetahui parameter kadar air, daya berkecambah, kadar karbohidrat, kadar lemak dan kadar protein benih kayu bawang selama proses pengeringan dan penyimpanan. Oleh karena itu tujuan penelitian adalah untuk menentukan karakteristik benih kayu bawang (Azadirachta excelsa (Jack) Jacobs) berdasarkan tingkat pengeringan dan ruang penyimpanan.

\section{METODOLOGI}

\section{A. Tempat dan Waktu}

Pengujian mutu benih dilaksanakan di laboratorium dan rumah kaca Balai Penelitian Teknologi Perbenihan Tanaman Hutan di Bogor. Pengujian analisis kandungan biokimia (karbohidrat, protein, lemak) dilakukan di Laboratorium Seameo-Biotrop di Bogor. Penelitian dilakukan selama 3 bulan, yaitu bulan FebruariMei 2014.

\section{B. Bahan dan Alat}

Benih kayu bawang yang digunakan berasal dari tegakan kayu bawang berumur 25 tahun di Hutan Penelitian Carita, Provinsi Banten. Peralatan yang digunakan berupa alat pengujian kadar air, alat pengujian analisis kandungan biokimia (karbohidrat, protein, lemak), bak kecambah, media tanah dan pasir yang telah disterilisasi, aluminium foil, silica gel, sprayer, aquades, ruang suhu kamar, AC, kulkas, alkohol, kantong kain blacu dan alat pengukur waktu.

\section{Metode}

\section{Pengunduhan buah}

Pengunduhan buah dilakukan dengan cara pemanjatan. Buah yang diunduh adalah buah 
yang sudah masak fisiologis, yaitu berwarna kuning. Jumlah pohon yang diunduh sebanyak 10 pohon dengan rata-rata diameter $60 \mathrm{~cm}$ dan tinggi total $30 \mathrm{~m}$.

\section{Ekstraksibenih}

Buah hasil pengunduhan langsung diekstraksi. Pengunduhan buah dilakukan selama 2 hari. Ekstraksi benih dilakukan dengan mencampur buah dengan pasir kasar dan kemudian menggosok dan melumatnya secara bersamaan dengan cara manual. Buah yang sudah lumat kemudian dicuci dengan air hingga daging dan kulitnya terlepas dari benihnya. Lamanya waktu ekstraksi benih, yaitu 1 hari.

\section{Pengujian I : Tingkat pengeringan benih}

Pada tahap pengujian I (tingkat pengeringan benih) dilakukan penujian dengan menggunakan Rancangan Acak Lengkap (RAL) dengan masing-masing perlakuan diulang sebanyak 4 kali. Perlakuan tingkat pengeringan yang digunakan dalam penelitian ini adalah berdasarkan lamanya waktu pengeringan, yaitu 0 , 24, 48, 72, 96, 120 jam. Perlakuan tingkat pengeringan di ruang kamar menggunakan satuan jam, untuk memudahkan dalam menentukan waktu dan disesuaikan dengan metode pengujian mutu benih di laboratorium. Selanjutnya benih dikeringkan di ruang kamar yang tertutup dengan suhu bervariasi $27-29^{\circ} \mathrm{C}$ dan kelembaban udara 70-80\%. Benih ditempatkan secara merata di tampah dan dilapisi dengan kertas merang. Untuk menentukan sampel pengujian benih di setiap perlakuan, maka diambil secara acak4 ulangan@5 gram benih untuk diuji kadar air, 100 gram benih untuk pengujian biokimia (protein, lemak, karbohidrat) dan diambil 4 ulangan@100 butir untuk pengujian daya berkecambah.

Respon yang diamati dalam penelitian ini adalah kadar air, kandungan biokimia (karbohidrat, protein, lemak) dan daya berkecambah. Pengujian kadar air benih menggunakan metode oven pada suhu $103 \pm 2^{\circ} \mathrm{C}$ selama 18 jam. Pengujian daya berkecambah menggunakan media campuran pasir dan tanah $(1: 1 \mathrm{v} / \mathrm{v}) \mathrm{di}$ rumah kaca. Analisis kandungan biokimia dilakukan di laboratorium Seameo-Biotrop di Bogor, yaitu menggunakan metode Luff Schoorl (karbohidrat), metode Soxhlet (lemak) dan protein (Kjeldhal). Data yang diperoleh selanjutnya dianalisis statistika menggunakan analisis sidik ragam dan uji lanjut beda rata-rata.

\section{Pengujian II: Tingkat pengeringan dan tempat penyimpanan benih}

Hasil pengujian pengringan bibit kayu bawang yang memiliki daya berkecambah di atas $60 \%$ yaitu tanpa pengeringan dan dikeringkan selama 24 jam. Selanjutnya dilakukan pengujian tahap II untuk mengetahui sejauhmana pengaruh tingkat pengeringan dan tempat penyimpanan benih. Penelitian menggunakan Rancangan Faktorial dalam Rancangan Acak Lengkap. Faktor pertama adalah faktor tingkat pengeringan yang terdiri atas 2 taraf, yaitu lama pengeringan 0 dan 24 jam. Faktor kedua ialah tempat penyimpanan benih terdiri atas 3 taraf yaitu ruang simpan pada suhu kamar, AC, kulkas. Setiap kombinasi perlakuan diulang 4 kali.

Untuk menentukan berat benih setiap kombinasi perlakuan diambil secara acak sebanyak 5 gram untuk pengujian kadar air, 100 gram untuk pengujian biokimia (karbohidrat, protein, lemak) dan 100 butir untuk pengujian daya berkecambah. Kemudian diberi silica gel yang beratnya sama dengan berat benih, yaitu 6.600 gram. Masing-masing benih yang telah dikeringkan 0 dan 24 jam, kemudian dikeluarkan dari kotak, lalu disimpan di masing-masing tempat penyimpanan benih, yaitu ruang suhu kamar (suhu $28-31^{\circ} \mathrm{C}$ dan RH 70-80\%), AC (suhu $18-20^{\circ} \mathrm{C}$ dan RH 50-60\%) dan kulkas (suhu 0-5 $5^{\circ} \mathrm{C}$ dan RH 40-50\%). Benih dibungkus rapat dengan menggunakan aluminium foil. Penyimpanan benih dari masing-masing ruang simpan dilakukan selama 14 hari. Setelah disimpan selama 14 hari, dilakukan pengukuran kadar air, daya berkecambah dan kandungan biokimia (karbohidrat, protein, lemak).

\section{HASIL DAN PEMBAHASAN}

\section{A. Hasil}

\section{Pengujian I : Karakteristik benih ber- dasarkan tingkat pengeringan}

Berdasarkan hasil sidik ragam menunjukkan bahwa perlakuan tingkat pengeringan berpengaruh nyata terhadap nilai kadar air, daya berkecambah, kadar lemak, karbohidrat dan protein benih kayu bawang. Untuk mengetahui lebih lanjut perlakuan yang menimbulkan perbedaan yang nyata, dilakukan uji Tukey (Tabel 1). 
Tabel(Table) 1. Uji Tukey rata-rata kadar air, daya berkecambah, kadar lemak, karbohidrat dan protein benih kayu bawang berdasarkan tingkat pengeringan (sebelum penyimpanan) (Tukey test for average of moisture content, germination rate, fat, carbohydrate and protein contents of kayu bawang seeds based on drying rate (before storage))

\begin{tabular}{cccccc}
\hline $\begin{array}{c}\text { Tingkat } \\
\text { pengeringan } \\
\text { (Drying rate })\end{array}$ & $\begin{array}{c}\text { Kadar air } \\
\text { (Moisture } \\
\text { content) }(\%)\end{array}$ & $\begin{array}{c}\text { Daya berkecambah } \\
(\text { Germination rate }) \\
(\%)\end{array}$ & $\begin{array}{c}\text { Lemak }(\text { Fat }) \\
(\%)\end{array}$ & $\begin{array}{c}\text { Karbohidrat } \\
(\text { Carbohydrate }) \\
(\%)\end{array}$ & $\begin{array}{c}\text { Protein } \\
(\%)\end{array}$ \\
\hline 0 & $57,21 \mathrm{a}$ & $83 \mathrm{a}$ & $17,04 \mathrm{e}$ & $9,07 \mathrm{a}$ & $12,69 \mathrm{c}$ \\
24 & $35,3 \mathrm{~b}$ & $62 \mathrm{~b}$ & $17,9 \mathrm{e}$ & $8,15 \mathrm{ab}$ & $12,75 \mathrm{c}$ \\
48 & $31,78 \mathrm{bc}$ & $48 \mathrm{c}$ & $20,4 \mathrm{~d}$ & $6,85 \mathrm{bc}$ & $13,28 \mathrm{bc}$ \\
72 & $31,57 \mathrm{bc}$ & $36 \mathrm{~d}$ & $23,57 \mathrm{c}$ & $6,4 \mathrm{~cd}$ & $13,46 \mathrm{bc}$ \\
96 & $29,15 \mathrm{bc}$ & $21 \mathrm{e}$ & $26,8 \mathrm{~b}$ & $5,9 \mathrm{~cd}$ & $15,6 \mathrm{ab}$ \\
120 & $28,49 \mathrm{bc}$ & $17 \mathrm{e}$ & $33,81 \mathrm{a}$ & $5,02 \mathrm{~d}$ & $17,09 \mathrm{a}$ \\
\hline
\end{tabular}

Keterangan (Remarks): Angka yang diikuti oleh huruf yang sama pada kolom yang sama tidak beda nyata pada tingkat nyata $5 \%$ (Values followed by the same letter at the same column are not significantly in the level of $5 \%$ )

Hasil lanjut uji beda rata-rata menunjukkan bahwa kadar air dan daya berkecambah benih kayu bawang dengan kondisi awal benih tidak dikeringkan menunjukkan kadar air dan daya berkecambah yang tertinggi dan berbeda signifikan dengan tingkat pengeringan $24,48,72$, 96 dan $120 \mathrm{jam}$. Pada tingkat pengeringan $24 \mathrm{jam}$ benih kayu bawang masih mampu menghasilkan daya berkecambah $62 \%$ dan kadar air 35,3\%. Benih kayu bawang yang dikeringkan lebih lama cenderung daya berkecambah dan kadar air semakin menurun. Benih kayu bawang yang tidak dikeringkan telah menghasilkan kadar lemak 17,04\%, kadar karbohidrat 9,07\% dan kadar protein $12,69 \%$. Semakin lama benih dikeringkan, maka kadar lemak dan protein semakin meningkat sedangkan kadar karbohidrat sebaliknya semakin menurun. Informasi dari Tabel 1 di atas, maka untuk mempertahankan daya berkecambah benih kayu bawang di atas $83 \%$ tidak perlu dikeringkan terlebih dahulu dan mempertahankan kadar air benih di atas $57 \%$. Kondisi tanpa pengeringan menunjukkan kadar karbohidrat 9,07\%, kadar lemak dan kadar protein tidak lebih dari $17,04 \%$ dan $12,69 \%$. Oleh karena itu, pengeringan benih kayu bawang hanya bisa dikeringkan selama 24 jam dengan daya berkecambah $62 \%$.

\section{Pengujian II: Karakteristik benih ber- dasarkan tingkat pengeringan dan tempat penyimpanan}

Hasil pengujian pengeringan benih kayu bawang hanya diambil 2 perlakuan, yaitu tanpa pengringan $(0 \mathrm{jam})$ dan pengeringan $24 \mathrm{jam}$. Pada tahap negujian II, benih kayu bawang yang telah dikeringkan 0 dan 24 jam selanjutnya disimpan di beberapa tempat penyimpanan benih lama 14 hari. Hasil analisis ragam menunjukkan bahwa faktor tingkat pengeringan dan faktor tempat penyimnanan benih berpengaruh signifikan terhadap daya berkecambah, kadar air, kadar karbohidrat dan kadar lemak benih kayu bawang sedangkan terhadap protein tidak berpengaruh nyata. Terjadi interaksi yang signfikan antara faktor tingkat pengeringan dengan tempat penyimpanan benih terhadap daya berkecambah, kadar air, kadar karbohidrat dan kadar lemak benih kayu bawang, namun terhadap kadar protein tidak terjadi interaksi yang signifikan.

Benih kayu bawang yang disimpan selama 14 hari menunjukkan bahwa ruang simpan $\mathrm{AC}$ dan tingkat pengeringan 0 jam memberikan pengaruh terhadap daya berkecambah, kadar air, kadar karbohidrat dan kadar lemak. Kedua faktor tersebut memberikan pengaruh yang berlawanan. Semakin baik kemampuan menyimpan benih di tempat penyimpanan benih, maka semakin tinggi daya berkecambah, kadar air dan kadar karbohidrat benih kayu bawang. Sebaliknya, semakin lama dikeringkan, maka semakin rendah daya berkecambah, kadar air dan kadar karbohidrat. Namun, semakin lama dikeringkan, maka persentase kadar lemak dan protein semakin meningkat, namun dampaknya terhadap daya berkecambah semakin menurun.

Hasil analisis interaksi antara tempat penyimpanan benih dan tingkat pengeringan menunjukkan bahwa interaksi faktor yang mempengaruhi daya berkecambah, kadar air dan kadar lemak adalah interaksi antara tempat penyimpanan benih dengan tingkat pengeringan pada saat benih kayu bawang dikeringkan selama 
0 dan 24 jam. Hasil analisis menunjukkan bahwa benih kayu bawang yang disimpan di ruang $\mathrm{AC}$, ruang kamar dan kulkas selama 14 hari ternyata daya kecambahnya rendah, yaitu masing-masing $29 \%, 28 \%$ dan $17 \%$. Benih kayu bawang setelah disimpan selama 14 hari di ruang simpan $\mathrm{AC}$ relatif mampu menahan kadar air benih, namun daya berkecambah benihnya drastis turun hampir 3 kali. Hal ini menunjukkan benih kayu bawang termasuk tipe benih rekalsitran yang cepat turun daya berkecambahnya. Hasil analisis interaksinya disajikan pada Tabel 2 .

Tabel(Table) 2. Interaksi faktor ruang simpan dan waktu simpan terhadap daya berkecambah, kadar air dan kadar lemak benih kayu bawang (Interaction of room storage and store period to germination rate, moisture and fat content of kayu bawang seeds)

\begin{tabular}{clcccc}
\hline $\begin{array}{c}\text { Waktu simpan } \\
\text { Store period) } \\
\text { Jam (Hours) }\end{array}$ & $\begin{array}{c}\text { Ruang penyimpanan } \\
\text { (Storage room) }\end{array}$ & $\begin{array}{c}\text { Daya } \\
\text { berkecambah } \\
\text { Germanation } \\
\text { rate) }(\%)\end{array}$ & $\begin{array}{c}\text { Kadar air } \\
\text { (Moisture } \\
\text { content) }(\%)\end{array}$ & $\begin{array}{c}\text { Kadar karbohidrat } \\
\text { (Carbohydrate } \\
\text { content) }(\%)\end{array}$ & $\begin{array}{c}\text { Kadar } \\
\text { lemak }(\text { Fat } \\
\text { content }) \\
(\%)\end{array}$ \\
\hline 0 & AC & $29,00 \mathrm{a}$ & $45,43 \mathrm{a}$ & $16,37 \mathrm{~b}$ & $11,57 \mathrm{~b}$ \\
0 & Kamar (Room) & $28,00 \mathrm{a}$ & $37,83 \mathrm{~b}$ & $17,58 \mathrm{ab}$ & $25,02 \mathrm{a}$ \\
0 & Kulkas (Refrigerator) & $17,00 \mathrm{~b}$ & $28,00 \mathrm{c}$ & $18,35 \mathrm{a}$ & $12,42 \mathrm{~b}$ \\
24 & AC & $27,00 \mathrm{a}$ & $34,52 \mathrm{~b}$ & $12,75 \mathrm{c}$ & $12,33 \mathrm{c}$ \\
24 & Kamar (Room) & $23,00 \mathrm{~b}$ & $37,58 \mathrm{a}$ & $16,62 \mathrm{a}$ & $26,98 \mathrm{a}$ \\
24 & Kulkas (Refrigerator) & $16,00 \mathrm{c}$ & $22,67 \mathrm{c}$ & $14,75 \mathrm{~b}$ & $15,17 \mathrm{~b}$ \\
\hline
\end{tabular}

Keterangan(Remarks): Angka yang diikuti oleh huruf yang sama pada kolom yang sama tidak beda nyata pada tingkat nyata $5 \%$ (Values followed by the same letter at the same column are not significantly in the level of $5 \%$ )

\section{B. Pembahasan}

Berdasarkan perlakuan tanpa pengringan (Tabel 1), benih kayu bawang mempunyai nilai kadar air awal 57,21\%, daya berkecambah $83 \%$, kadar lemak 17,04\%, kadar karbohidrat 9,07\% dan kadar protein $12,69 \%$. Hasil nilai kadar air ini memberikan indikasi bahwa benih kayu bawang termasuk ke dalam benih rekalsitran. Hal ini karena salah satu indikasi yang dipakai untuk menggolongkan jenis benih tertentu adalah dengan melihat kadar air awalnya. Selain itu, nilai kandungan biokimia awal (kontrol) juga menunjukkan bahwa benih kayu bawang memiliki kadar lemak lebih tinggi dibandingkan dengan kadar karbohidrat dan kadar protein.

Kadar air benih kayu bawang mengalami penurunan pada pengeringan selama 24 jam $(35,30 \%)$ dan terus menurun sampai pengeringan 48 jam $(31,78 \%)$. Pada pengeringan 48 jam sampai 120 jam $(28,49 \%)$, kadar air relatif stabil dan tidak memberikan nilai kadar air yang berbeda nyata. Diduga kadar air benih kritis benih kayu bawang mendekati kadar air 35-57\%. Pada kondisi ini, menghasilkan daya berkecambah $62 \%$, kadar karbohidrat 17,9\%, kadar lemak $8,15 \%$ dan kadar protein $12,75 \%$. Lama pengeringan dan ruang penyimpanan berpengaruh nyata terhadap nilai kadar air, daya berkecambah dan kandungan biokimia (lemak, karbohidrat, protein) benih kayu bawang. Semakin lama dikeringkan dan disimpan, maka kadar air benih, daya berkecambah benih dan kadar karbohidrat terus menurun, namun kadar lemak dan proteinnya meningkat.

Hasil penelitian menunjukkan bahwa daya berkecambah benih kayu bawang cenderung menurun seiring dengan pengeringan dan penyimpanan yang lama. Benih kayu bawang termasuk benih rekalsitran dan diduga bisa disimpan kurang dari 7 hari. Benih rekalsitran tidak tahan terhadap pengeringan dan tidak dapat disimpan pada temperatur rendah, sehingga tidak mampu disimpan lama. Hasil penelitian yang telah dilakukan peneliti terdahulu bahwa untuk mempertahankan viabilitas benih rekalsitran diperlukan kadar air minimal tetap tinggi (20$35 \%$ ) pada suhu penyimpanan $12-15^{\circ} \mathrm{C}$ dan beberapa jenis pada suhu $15-20^{\circ} \mathrm{C}$. Pada umumnya benih rekalsitran memiliki kadar air awal benih bervariasi 30-70\%. Benih kayu bawang bisa dipertahankan kadar airnya sampai $37-45 \%$ selama 14 hari di ruang AC dan ruang kamar, namun daya berkecambahnya turun drastis. Daya simpan benih rekalsitran bervariasi dari beberapa hari untuk benih rekalsitran yang ekstrim sampai beberapa bulan untuk benih rekalsitran yang toleran. Penyimpanan benih rekalsitran meliputi benih mimba (Azadirachta 
indica), damar (Agathis loranthifolia), rotan manau (Calamus manan), Gmelina arborea, ramin (Gonystylus bancanus), Makadamia (Macadamia hildebrandii) dan jenis-jenis meranti (Shorea spp.) dengan cara konvensional hanya mampu mempertahankan viabilitasnya selama 1-5 minggu. Semakin lama proses pengeringan dan penyimpanan dari benih rekalsitran, akan menyebabkan menurunnya nilai kadar air, sehingga mengakibatkan daya berkecambah juga menurun. Sejalan dengan menurunnya kadar air dan daya berkecambah selama proses pengeringan dan penyimpanan, menyebabkan kadar lemak dan kadar protein cenderung meningkat sedangkan kadar karbohidrat menurun. Benih yang memiliki kadar lemak yang tinggi akan cepat rusak, sehingga benih akan cepat mati dan menurun daya berkecambahnya. Kadar protein yang meningkat akan menyebabkan aktifitas metabolisme dalam benih juga meningkat. Kadar karbohidrat menurun, dapat menyebabkan menurunnya pertahanan benih, sehingga hal ini yang dapat mengakibatkan daya berkecambah (viabilitas benih) menurun.

Salah satu faktor yang mempengaruhi periode hidup benih adalah kadar air benih, karena kadar air benih merupakan faktor yang menentukan dalam kemunduran benih (Yuniarti, et al., 2013). Kemunduran benih yang disebabkan penurunan kadar air yang diindikasikan secara fisiologi dengan adanya perubahan warna benih, tertundanya perkecambahan, menurunnya kemampuan berkecambah dan meningkatnya kecambah abnormal.

Kemunduran benih rekalsitran akibat faktor internal maupun eksternal ditandai dengan penurunan daya berkecambah, peningkatan jumlah kecambah abnormal, penurunan pemunculan kecambah di lapangan (field emergence), terhambatnya pertumbuhan dan perkembangan tanaman, meningkatnya kepekaan terhadap lingkungan yang ekstrim yang akhirnya dapat menurunkan produksi tanaman (Panjaitan, 2010).

Salah satu masalah yang dihadapi dalam usaha penyediaan benih bermutu tinggi adalah usaha mempertahankan viabilitas benih selama penyimpanan, yaitu dengan cara menurunkan laju respirasi. Laju respirasi yang terlalu tinggi dapat mengakibatkan benih cepat kehilangan energi dan persediaan cadangan makanan terutama pada daerah embrio. Habisnya bahan cadangan makanan pada embrio dapat meng- akibatkan benih tidak mampu berkecambah dan ini adalah proses kemunduran benih (Widajati et al., 2012).

Secara umum benih kayu bawang yang disimpan di ruang $\mathrm{AC}$ dapat menghasilkan viabilitas benih yang lebih baik dibandingkan dengan di ruang kamar dan kulkas. Selain itu juga dapat mempertahankan nilai kadar air tetap tinggi, seperti yang diperlukan oleh benih rekalsitran.

Sifat benih kayu bawang selama penyimpanan menunjukkan karakteristik rekalsitran dimana suhu penyimpanan yang dapat mempertahankan viabilitas benih adalah pada suhu ruang $\mathrm{AC}$ yaitu antara $20-22^{\circ} \mathrm{C}$ dan hanya bisa dismpan dalam waktu yang singkat. Benih rekalsitran Trichilia emetica ditemukan rusak setelah disimpan pada suhu $6^{\circ} \mathrm{C}$ (Kioko et al., 2006), juga benih T. occidentalis (Ajayi et al., 2006). Cara terbaik untuk mempertahankan viabilitas benih rekalsitran adalah menyimpannya pada suhu rendah dimana benih rekalsitran paling tahan, di bawah kondisi tidak kehilangan kadar air dan mengurangi kontaminasi dengan jamur (Berjak \& Pammenter, 2008).

Kelembaban nisbi pada ruang simpan berpengaruh langsung terhadap kadar air sedangkan faktor suhu suhu ruang dapat meningkatkan laju reaksi biokimia benih. Periode hidup benih dalam penyimpanan dapat dipengaruhi oleh suhu lingkungan simpan atau kelembaban nisbi lingkungan simpan dan kadar air benih (Harnowo, 2006). Ada beberapa ruang simpan yang cocok untuk benih berwatak rekalsitran seperti benih kayu bawang, yaitu ruang suhu kamar (suhu $25-30^{\circ} \mathrm{C}$, kelembaban nisbi $70-80 \%$ ) dan ruang simpan kering sejuk (suhu $18-20^{\circ} \mathrm{C}$, kelembaban nisbi 50-60\%), seperti ruang simpan AC.

Dilihat dari kandungan biokimia (lemak, karbohidrat, protein), proses penyimpanan, benih kayu bawang mengalami peningkatan kadar lemak dan protein serta menurunnya kadar karbohidrat. Kandungan asam lemak yang tinggi di dalam benih juga merupakan indikasi terjadinya proses respirasi yang tinggi yang menyebabkan benih kehilangan energi untuk perkecambahan (Yuniarti et al., 2008c).

Pada proses pengeringan (penurunan kadar air) kandungan lemak pada benih cenderung meningkat sejalan dengan menurunnya kadar air dan daya berkecambah (Yuniarti et al., 2008a). Pengeringan ini merupakan faktor penyebab terjadinya kemunduran benih. Kadar air benih 
merupakan faktor yang penting sehubungan dengan pengaruhnya terhadap viabilitas benih (Rohandi \& Widyani, 2010).

Peningkatan kandungan lemak dan protein pada benih diduga merupakan mekanisme pertahanan benih terhadap penurunan kadar air. Peningkatan kandungan lemak menyebabkan terhambatnya metabolisme benih. Metabolisme benih yang terganggu mengakibatkan penurunan viabilitas (Yuniarti et al., 2008b). Penurunan kadar air dan peningkatan asam lemak bebas menyebabkan penurunan viabilitas dan vigor benih. Gejala kemunduran secara biokimia pada benih adalah perubahan dalam aktivitas enzim, laju respirasi, peningkatan asam lemak dan berkurangnya persediaan cadangan makanan. Kandungan asam lemak yang tinggi di dalam benih merupakan indikasi terjadinya akumulasi asam lemak, karena tidak diproses lebih lanjut menjadi energi, sehingga benih kehilangan energi untuk berkecambah (Tresniawati et al., 2014).

Benih dengan kandungan lemak tinggi memerlukan perhatian khusus dalam penanganannya, kalau tidak maka akan berakhir dengan kehilangan viabilitas dan kemampuan berkecambah (Balesevic-Tubic et al., 2007). Liu et al. (2006) memperlihatkan bahwa proporsi asam lemak dalam membran fosfolipid pada benih rekalsitran lebih tinggi daripada benih ortodok. Pada beberapa kasus ditemukan bahwa meningkatnya kandungan lemak karena adanya jamur selama penyimpanan dalam kondisi lembab seperti terjadi pada jarak (Jatropha curcas) (Worang et al., 2008). Kandungan asam lemak yang tinggi di dalam benih juga merupakan indikasi terjadinya proses respirasi yang tinggi yang menyebabkan benih kehilangan energi untuk perkecambahan.

Selama penyimpanan kandungan protein pada benih kayu bawang juga cenderung meningkat sejalan dengan menurunnya kadar air dan daya berkecambah. Perubahan intensitas dan jenis protein dikontrol oleh DNA yang menyesuaikan dengan aktivitas di dalam benih itu sendiri. Peningkatan kandungan protein ini diduga merupakan mekanisme pertahanan benih terhadap penurunan kadar air dan lama penyimpanan.

Sementara itu, kandungan karbohidrat pada benih kayu bawang justru semakin menurun selama penyimpanan. Keberadaan karbohidrat dalam benih yang terdiri dari komponen gula (sukrosa) sebagai substrat pembentuk karbohidrat, menunjukkan adanya pertahanan terhadap pengeringan seperti halnya protein. Terjadinya penurunan kandungan karbohidrat mengindikasikan penurunan pertahanan benih artinya terjadi penurunan viabilitas benih. Hal ini ditunjukkan dengan menurunnya daya berkecambah benih kayu bawang selama penyimpanan.

\section{KESIMPULAN DAN SARAN}

\section{A. Kesimpulan}

Benih kayu bawang termasuk ke dalam karakteristik benih reklasitran dengan kadar air awal $57,21 \%$, daya berkecambah $83 \%$, kadar lemak 17,04\%, kadar karbohidrat 9,07\% dan kadar protein $12,69 \%$. Semakin lama pengeringan mengakibatkan menurunnya kadar air, daya berkecambah dan kadar karbohidrat, tetapi kadar lemak dan protein meningkat. Benih kayu bawang tidak perlu dikeringkan dan hanya mampu disimpan dalam waktu singkat.

\section{B. Saran}

Ruang simpan benih kayu bawang yang berwatak rekalsitran membutuhkan ruang kamar dengan suhu $25-30^{\circ} \mathrm{C}$, kelembaban nisbi $70-80 \%$ atau di ruang simpan $\mathrm{AC}$ dengan kondisi ruangan yang kering sejuk yaitu suhu $18-20^{\circ} \mathrm{C}$ dan kelembaban nisbi 50-60\%. Benih kayu bawang termasuk benih rekalsitran yang cepat turun daya berkecambahnya, oleh karena itu setelah pengunduhan benih agar segera disemaikan.

\section{UCAPAN TERIMA KASIH}

Penulis mengucapkan terima kasih kepada Kantor Pusat Penelitian dan Pengembangan Hutan atas kerjasama yang baik dalam memberikan materi benih di lokasi Hutan Penelitian Carita, Banten untuk keperluan penelitian ini. Terima kasih juga kami ucapkan kepada Ateng Rahmat Hidayat, S.Hut yang telah membantu dalam pelaksanaan pengujian di laboratorium Balai Penelitian Teknologi Perbenihan Tanaman Hutan di Bogor. 


\section{DAFTAR PUSTAKA}

Ajayi, S.A., Berjak, P., Kioko, J., Dulloo, M.E., \& Vodouhe, R.S. (2006). Responses of fluted pumpkin (Telfairia occidentalis Hook.f.) seeds to desiccation, chilling and hydrated storage. South African Journal of Botany, 72, 544-550.

Balešević-Tubić, S., Tatić, M., Miladinović, J., Pucarević, M. (2007). Changes of faty acidscontent and vigour of sunflower seed during natural aging. Helia, 30(47), 61-67.

Berjak, P., \& Pammenter, N.W. (2008). From Avicennia to zizania: seed recalcitrance in perspectiv. Ann Bot (Lond), 101(2), 213-228.

Harnowo, D. (2006). Teknologi penanganan benih tanaman pangan guna menghasilkan benih bermutu tinggi. Makalah pada Pelatihan Penangkaran Benih Tanaman Pangan seluruh Nusa Tenggara Barat, dilaksanakan oleh Dinas Pertanian Provinsi Nusa Tenggara Barat, 12-15 September 2006.

Kioko, J.I., Berjak, P., \& Pammenter, N.W.. (2006). Viability and ultrastructural responses of seeds and embryonic axes of Trichilia emetica to different dehydration and storage conditions. South African Journal of Botany, 71, 167-176.

Tatipata, A. (2008). Pengaruh kadar air awal, kemasan dan lama simpan terhadap protein membran dalam mitokondria benih kedelai. Buletin Agronomi 36(1): 8-16.

Tresniawati, C., Murniati, E., \& Widayati, E. (2014). Perubahan fisik, fisiologi dan biokimia selama pemasakan benih dan studi rekalsitransi benih kemiri sunan. Jurnal Agronomi Indonesia, 42(1), 74-79.

Liu M.S., Chang, C.Y., Lin, T.P. (2006). Comparison of phospholipids and their fatty acids in recalcitrant and orthodox seeds. Seed Science and Technology, 34, 443-452.

Panjaitan, S. (2010). Kemunduran mutu benih rekalsitran. panjaitansumitro.blogspot.com/. Diakses tanggal 9 Pebruari 2015.

Rohandi, A., \& Widyani, N. (2010). Dampak penurunan kadar air terhadap respon fisiologis dan biokimia propagul Rhizophora apiculata B1. Jurnal Penelitian Hutan Tanaman, 7(4), 167-179.
Syamsuwida, D., \& Aminah, A. (2007). Perubahan kandungan lemak, protein, pati dan daya hantar listrik pada benih gaharu (Aquillaria malaccensis). Jurnal Manajemen Hutan Tropika, 13(2), 125-130.

Widajati, E., Murniati, E., Palupi, E.R., Kartika, T., Suhartanto, M.R. \& Qadir, A. (2012). Dasar ilmu dan teknologi benih. IPB Press. Bogor.

Worang, R.L., Dharmaputra, Q.S., Syarief, R., \& Miftahudin. (2008). The quality of physic nut (Jatropha curcas L.) seeds packed in plastic material during storage. Biotropia, 15(1), 2536.

Yuniarti, N., Syamsuwida, D., \& Aminah, A. (2008a). Dampak pengeringan terhadap perubahan fisiologi dan biokimia benih Mimba (Azadirachta indica A.Jusss). Buletin Puslitbang Perhutani, 11(1), 728-735.

Yuniarti, N., Syamsuwida, D., \& Aminah, A. (2008b). Pengaruh penurunan kadar air terhadap perubahan fisiologi dan kandungan biokimia benih eboni (Diospyros celebica Bakh.). Jurnal Penelitian Hutan Tanaman, 5(3), 191198.

Yuniarti, N., Syamsuwida, D., \& Aminah, A. (2008c). Perubahan kandungan biokimia dan fisiologi benih mimba (Azadirachta indica A.Jusss) selama penyimpanan. Jurnal Penelitian Hutan Tanaman, 5(2), 259-267.

Yuniarti, N., Suita, E., Zanzibar, M., \& Nurhasybi. (2011). Teknik penanganan benih tanaman hutan. Prosiding Seminar Hasil-hasil Penelitian Teknologi Perbenihan untuk Meningkatkan Produktivitas Hutan Rakyat Di Propinsi Jawa Tengah.

Yuniarti, N., Syamsuwida, D., \& Aminah, A. (2013). Dampak perubahan fisiologi dan biokimia benih eboni (Diospyros celebica Bakh.) selama penyimpanan. Jurnal Penelitian Hutan Tanaman, 10(2), 65-71.

Yuniarti, N., Megawati, \& Leksono, B. (2013). Pengaruh metode ekstraksi dan ukuran benih terhadap mutu fisik-fisiologis nenih Acacia crassicarpa. Jurnal Penelitian Hutan Tanaman, 10(3), 129-146. 